\title{
Establishing a standard for handmade Brazilian cassava flour from Baixada Cuiabana (Mato Grosso, Brazil) to support its processing and sale
}

\author{
Ozeni Souza de OLIVEIRA ${ }^{1}$, Vitor Hugo dos Santos BRITO ${ }^{1}$, Marney Pascoli CEREDA ${ }^{1 *}$
}

\begin{abstract}
The Baixada Cuiabana region contains the confluence of the Brazilian Savannah, Amazon and wetlands biomes. This region brings together small producers of cassava who prepare dry flour by hand, maintaining a bank of active ethno-varieties of this crop and that are of cultural, social, economic and genetic importance. This study aimed to establish a standard for the flour currently being processed and marketed. Thus, 26 samples were collected from seven municipalities of the region. At the time of this sampling, the predominant standard of the handmade cassava flour produced in Baixada Cuiabana was Dry group, Medium class, yellow-colour, of Types 1, 2 and 3. Using the Hunter Lab colour system, the predominant colour was found to be yellow with red or green tonality, with one sample artificial colorant. Consumers recognize granule size and colour as the main parameters that determine purchase of the product. Seven samples from four municipalities were classified as Out of Type, because they presented values in disagreement with legislation that could result in difficulties in valorisation and sale in the legal market.
\end{abstract}

Keywords: legislation; colour; granulometry; composition; ethno-varieties.

Practical Application: Possibility to direct the process to obtain the type of flour preferred by the consumer.

\section{Introduction}

The Baixada Cuiabana region represents a special area of Brazil because it contains the confluence of the Savannah, Amazon, and Wetlands biomes and ecotone areas. This region concentrates small producers of cassava who process their flour in artisanal units, which hold economic and social importance for these small producers. The cultivation of cassava in the region constitutes an active germplasm bank that depends on the commercialization of cassava flour. The ecological balance of the region depends on consumers continuing to visit 14 municipalities to buy the flour, so it continues to be produced, and the cultivation of ethno-diversity is maintained to preserve this gene pool.

To be sold, cassava flour must meet the criteria set out in Normative Instruction No. 52 of November 7, 2011, which establishes strict limits for classification and categorization as standards of standard and quality for flour (Brasil, 2011), which, due to cultural aspects, presents different characteristics in each region of Brazil (Cereda \& Vilpoux, 2010).

Depending on processing, flours are separated into the groups Dry, D'Água and Bijusada and the granulometric classes Fine, Medium and Coarse. Flour may still be disqualified or unfit for consumption due to the presence of contaminants such as insects and molds or odours from improper storage (Brasil, 2011; Mundin et al., 2015). Another important point in flour quality is the presence of artificial colorants, such as tartrazine (Functional class colour - INS 102 Food Additive Index Codex Alimentarius), which are responsible for triggering allergies and asthma and for carcinogenic activity, causing consumer health risks (Prado \& Godoy, 2003; Oliveira et al., 2014).
Although a large part of the flour sold in Brazil is made with a mechanized process (Cereda \& Vilpoux, 2010), some regional products obtained in an artisanal way remain valued, as is the case with traditional Copioba cassava flour in Bahia (Silva et al., 2016) and Farinha D'água in the northern region of the country (Chisté et al., 2007; Cereda \& Vilpoux, 2010). The valorisation of artisanal farms by consumers takes into account the socio-cultural aspects in the environments in which cassava flour is manufactured and favours the development of local communities.

In the specific case of Baixada Cuiabana, Mato Grosso, the production of cassava and flour are in the process of being recognized as part of the local historical and cultural heritage. However, Souza \& Amaral (2015) highlighted negative factors that could potentially compromise the permanence of these small processors, such as decreasing root production, shortages of labour and modernization of processing.

The present work aimed to establish an standard for the artisanal flour produced in the region of Baixada Cuiabana (Mato Grosso, Brazil) while considering the limits of quality established by the Brazilian Normative Instruction.

\section{Materials and methods}

During the period from June to August 2015, 26 samples of cassava flour (1 kg each) were collected from rural communities in 7 municipalities in the region of Baixada Cuiabana 
(Figure 1 and Table 1), representing 50\% of all municipalities in the region. Sampling was performed according to the number of flour houses available in each municipality.

The criteria for cassava flour classification were established in RDC regulation No. 52 of the Ministry of Agriculture, Livestock and Supply - MAPA (Brasil, 2011), including the limits for ranking cassava flour by class and type as a function of centesimal composition and particle size.

The samples transported to the laboratory are conditioned in glass bottles at room temperature for further analysis.

\subsection{Analysis}

\section{Granulometry}

The granulometry profile was established according to Brasil (2011) with particle size separation in sieves with apertures of $2.00,1.7,1.0$, and $<1.0 \mathrm{~mm}$.

\section{Colour}

Sample colours were measured in a Minolta ${ }^{\circledR}$ (CR 400,Chroma Meter, Sensing Americas) colorimeter using the Hunter Lab colour system with luminosity ( 0 to $100 \%$ ), shades in - a (green), $+\mathrm{a}$ (red), - b (blue) and $+\mathrm{b}$ (yellow) (Dias \& Leonel, 2006). To illustrate the colour parameters, the flours were imaged in their original granulometry.

\section{Artificial colorant}

The presence of artificial colorants was detected using the methodology MA-E-AS315-08-COLSYN (International Organization of Vine and Wine, 2012). The method is reference in IN-24 by the Ministry of Agriculture, Livestock and Supply (Brasil, 2005). It is based on the extraction and fixation of the dye in natural sheep wool in order to provide perceptible coloration. The discoloured sheep's wool is the standard for a sample without artificial colorant. The tests use a hydroalcoholic

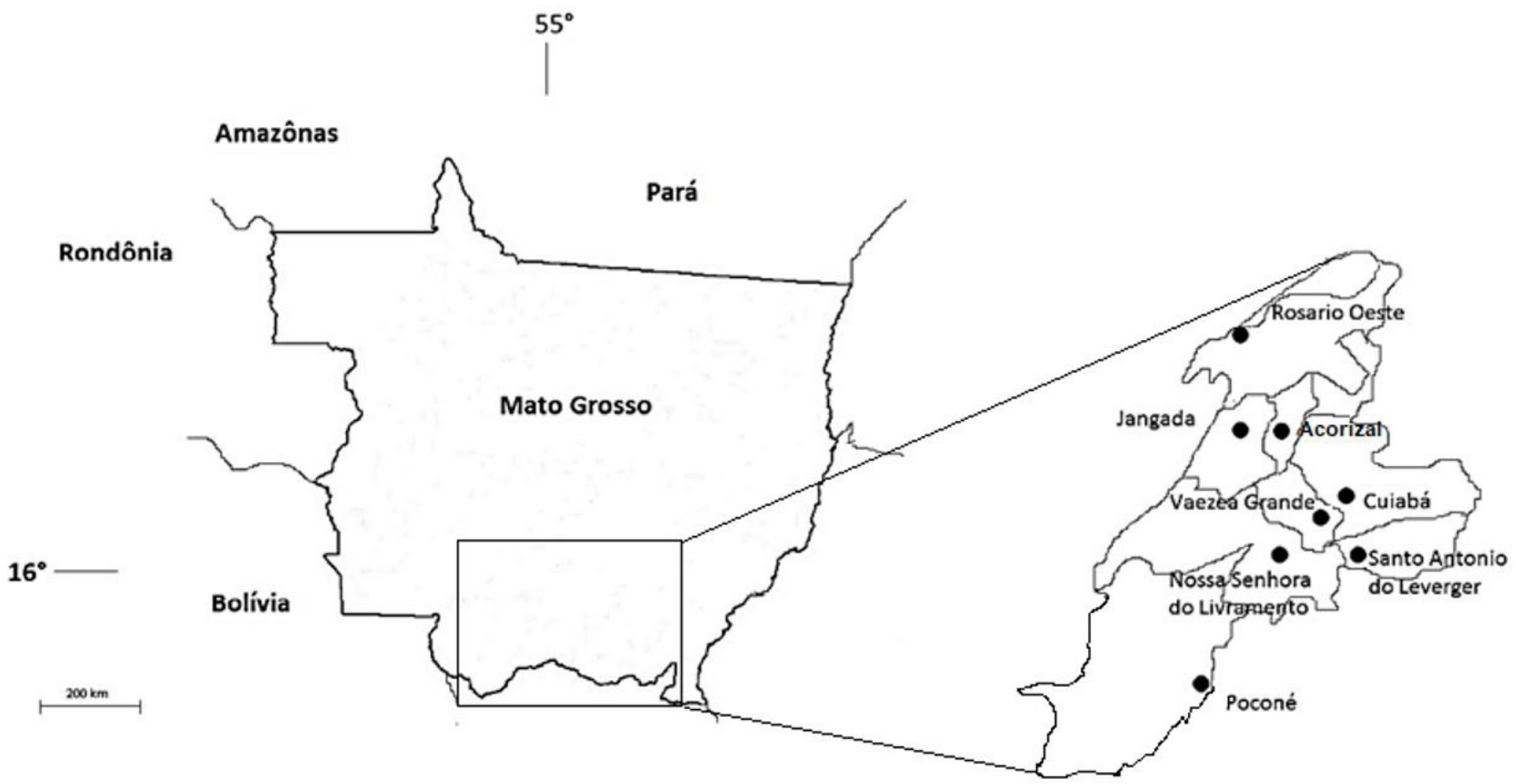

Figure 1. Location of the municipalities of Baixada Cuiabana, target of the study in State of Mato Grosso. Source: Adapted from information from the Brazilian Institute of Geography and Statistics (Instituto Brasileiro de Geografia e Estatística, 2016).

Table 1. Municipalities and specifications of cassava flour samples collected from Baixada Cuiabana region, Mato Grosso, between June and August 2015.

\begin{tabular}{|c|c|c|}
\hline Municipalities & Geographic Coordinates & Samples \\
\hline Rosário Oeste & $\mathrm{S}^{\prime} 4^{\circ} 89^{\prime} 31.246^{\prime \prime} \mathrm{W} 56^{\circ} 114^{\prime} 22^{\prime \prime}$ & $\mathrm{A}, \mathrm{B}, \mathrm{C}, \mathrm{D}$ \\
\hline Nossa Senhora do Livramento & $\mathrm{S} 15^{\circ} 87^{\prime} 44.34^{\prime \prime} \mathrm{W} 56^{\circ} 18.40^{\prime} 54^{\prime \prime}$ & $\mathrm{E}, \mathrm{F}, \mathrm{G}, \mathrm{H}$ \\
\hline Jangada & $\mathrm{S}_{15}^{\circ} 32^{\prime} 150.26^{\prime \prime} \mathrm{W} 56^{\circ} 49^{\prime} 22^{\prime \prime}$ & I, J, K \\
\hline Cuiabá & S $15^{\circ} 35^{\prime} 14^{\prime \prime}$ W $56^{\circ} 22^{\prime} 99^{\prime \prime} / \mathrm{S} 15^{\circ} 40^{\prime} 00.1^{\prime \prime} \mathrm{W} 55^{\circ} 42^{\prime} 00.0^{\prime \prime}$ & $\mathrm{L}, \mathrm{M}, \mathrm{N}, \mathrm{O}, \mathrm{P}, \mathrm{Q}$ \\
\hline Acorizal & $\mathrm{S} 15^{\circ} 21^{\prime} 83.31^{\prime \prime} \mathrm{W} 56^{\circ} 33.03^{\prime} 99^{\prime \prime}$ & $\mathrm{R}, \mathrm{S}, \mathrm{T}, \mathrm{U}, \mathrm{V}, \mathrm{W}$ \\
\hline Santo Antônio do Leverger & $\mathrm{S} 15^{\circ} 86^{\prime} 46.91^{\prime \prime} \mathrm{W} 56^{\circ} 06.95^{\prime} 24^{\prime \prime}$ & $\mathrm{X}, \mathrm{Y}$ \\
\hline Poconé & $\mathrm{S} 16^{\circ} 26^{\prime} 46.27^{\prime \prime} \mathrm{W} 56^{\circ} 63.22^{\prime} 49^{\prime \prime}$ & $\mathrm{Z}$ \\
\hline
\end{tabular}


extraction (10\% v: v) with $10 \mathrm{~g}$ of flour in $100 \mathrm{~mL}$ of extractive solution and homogenized for 5 hours.

\section{Physical-chemical composition}

Measurements of moisture, titratable acidity and ash were performed using procedures described by the Association of Official Analytical Chemists (2000) The starch content was indirectly measured by quantifying the reducing sugars after hydrolysis using Licozyme ${ }^{\circledR}$ commercial amylase with an alpha-amylase activity of $120 \mathrm{KNU}^{-\mathrm{T} \mathrm{g}^{-1}}$ followed by $\mathrm{AMG}^{\circledR}$ with $300 \mathrm{AGU} \mathrm{ml}^{-1}$ glucoamylase activity. After hydrolysis, the glucose content released was determined by the method of Somogyi (1945) and Nelson (1944) and expressed as a starch concentration by multiplying its value by 0.9 , according to Demiate et al. (2001). The crude fibre content was measured according to the Association of Official Analytical Chemists (2000). All the analyses are expressed in Dry Basis (DB).

\subsection{Data analysis}

All analyses were performed with five replicates, and the results were expressed as the means and standard deviations. The averages were compared by Turkey's test at the $5 \%$ probability level ( $\mathrm{p}<0.05)$, and graphical plots were produced using the Statsoft (2016).

\section{Results and discussion}

Despite local variations, all rural communities in the Baixada Cuiabana region maintained the minimum processing flow of cassava flour of the Dry group as specified in the literature, including harvesting, transportation, peeling, washing, sorting, grating, pressing, oven drying, cooling, sorting by sieve and packaging.

The granulometric profile of the samples shown in Table 2, visually shows the particle size. This study necessarily followed the criteria of regulation No. 52 (Brasil, 2011) for the classification

Table 2. Granulometry and classification of cassava flour from Baixada Cuiabana (Mato Grosso Brazil) sampled from June to August 2015.

\begin{tabular}{|c|c|c|c|c|c|}
\hline \multirow{2}{*}{ Municipalities/Samples } & \multicolumn{5}{|c|}{ Granulometry of the cassava flour (\% of retaijed sample)* } \\
\hline & $2 \mathrm{~mm}$ & $1.7 \mathrm{~mm}$ & $1.0 \mathrm{~mm}$ & $<1.0 \mathrm{~mm}$ & Class \\
\hline \multicolumn{6}{|l|}{ Rosário Oeste } \\
\hline A & $6.17 \pm 2.0 \mathrm{fg}$ & $27.00 \pm 0.7 \mathrm{de}$ & $27.00 \pm 0.7 \mathrm{de}$ & $56.00 \pm 0.2 \mathrm{~h}$ & Medium \\
\hline $\mathrm{B}$ & $4.54 \pm 0.30 \mathrm{ij}$ & $26.45 \pm 0.2 \mathrm{ef}$ & $26.45 \pm 0.3 \mathrm{ef}$ & $62.10 \pm 0.7 \mathrm{fg}$ & Medium \\
\hline $\mathrm{C}$ & $3.39 \pm 0.1 \mathrm{k}$ & $31.87 \pm 0.3 b$ & $31.87 \pm 0.1 b$ & $48.10 \pm 0.5 \mathrm{k}$ & Medium \\
\hline $\mathrm{D}$ & $7.37 \pm 0.1 \mathrm{de}$ & $29.27 \pm 0.3 c$ & $29.27 \pm 0.1 \mathrm{c}$ & $49.75 \pm 0.5 \mathrm{j}$ & Medium \\
\hline \multicolumn{6}{|c|}{ Nossa Senhora do Livramento } \\
\hline $\mathrm{E}$ & $2.39 \pm 0.11$ & $23.99 \pm 0.2 \mathrm{~g}$ & $23.99 \pm 0.2 \mathrm{~g}$ & $45.94 \pm 0.11$ & Medium \\
\hline $\mathrm{F}$ & $8.24 \pm 0.1 \mathrm{c}$ & $28.19 \pm 0.3 \mathrm{~cd}$ & $28.19 \pm 0.0 \mathrm{~cd}$ & $49.05 \pm 0.6 \mathrm{jk}$ & Medium \\
\hline G & $7.32 \pm 0.1 \mathrm{de}$ & $27.45 \pm 0.1 \mathrm{de}$ & $27.45 \pm 0.0 \mathrm{de}$ & $50.06 \pm 0.6 j$ & Medium \\
\hline $\mathrm{H}$ & $3.60 \pm 0.4 \mathrm{k}$ & $25.64 \pm 0.2 \mathrm{f}$ & $25.64 \pm 0.2 \mathrm{f}$ & $63.41 \pm 0.4 \mathrm{ef}$ & Medium \\
\hline \multicolumn{6}{|l|}{ Jangada } \\
\hline I & $3.46 \pm 0.2 \mathrm{k}$ & $20.21 \pm 0.01$ & $20.21 \pm 0.21$ & $71.35 \pm 0.0 \mathrm{c}$ & Medium \\
\hline$J$ & $18.90 \pm 0.5 \mathrm{a}$ & $22.10 \pm 0.7 \mathrm{hij}$ & $22.10 \pm 0.1 \mathrm{hij}$ & $50.27 \pm 0.4 j$ & Coarse \\
\hline $\mathrm{K}$ & $18.60 \pm 0.2 \mathrm{a}$ & $21.81 \pm 0.2 \mathrm{j}$ & $21.81 \pm 0.2 \mathrm{j}$ & $49.98 \pm 0.1 \mathrm{j}$ & Coarse \\
\hline \multicolumn{6}{|l|}{ Cuiabá } \\
\hline $\mathrm{L}$ & $14.45 \pm 0.0 \mathrm{a}$ & $8.65 \pm 0.5 \mathrm{~m}$ & $8.65 \pm 0.2 \mathrm{~m}$ & $73.19 \pm 0.3 \mathrm{~b}$ & Coarse \\
\hline M & $5.62 \pm 0.1 \mathrm{gh}$ & $26.50 \pm 0.1 \mathrm{ef}$ & $26.50 \pm 0.3 \mathrm{ef}$ & $60.53 \pm 0.4 \mathrm{~g}$ & Medium \\
\hline $\mathrm{N}$ & $16.75 \pm 0.4 \mathrm{a}$ & $32.89 \pm 0.2 \mathrm{~b}$ & $32.89 \pm 0.6 b$ & $39.66 \pm 0.8 \mathrm{~m}$ & Coarse \\
\hline $\mathrm{O}$ & $12.89 \pm 0.1 \mathrm{~b}$ & $24.08 \pm 0.1 \mathrm{~g}$ & $24.08 \pm 0.1 \mathrm{~g}$ & $56.16 \pm 0.2 \mathrm{~h}$ & Coarse \\
\hline $\mathrm{P}$ & $6.36 \pm 0.5 \mathrm{fg}$ & $22.55 \pm 0.4$ hij & $22.55 \pm 0.3$ hij & $64.59 \pm 0.4 \mathrm{e}$ & Medium \\
\hline $\mathrm{Q}$ & $26.63 \pm 0.2 \mathrm{a}$ & $22.63 \pm 0.2 \mathrm{hij}$ & $22.63 \pm 0.2 \mathrm{hij}$ & $41.11 \pm 0.2 \mathrm{~m}$ & Coarse \\
\hline \multicolumn{6}{|l|}{ Acorizal } \\
\hline $\mathrm{R}$ & $5.53 \pm 0.1 \mathrm{gh}$ & $34.43 \pm 0.2 \mathrm{a}$ & $34.43 \pm 0.5 a$ & $49.17 \pm 0.3 \mathrm{jk}$ & Medium \\
\hline $\mathrm{S}$ & $7.53 \pm 0.3 \mathrm{~cd}$ & $21.69 \pm 0.0 \mathrm{j}$ & $21.69 \pm 0.3 j$ & $63.44 \pm 0.0 \mathrm{ef}$ & Medium \\
\hline $\mathrm{T}$ & $16.09 \pm 0.5 \mathrm{a}$ & $26.61 \pm 0.4 \mathrm{ef}$ & $26.61 \pm 0.4 \mathrm{ef}$ & $45.37 \pm 0.61$ & Coarse \\
\hline $\mathrm{U}$ & $5.13 \pm 0.0 \mathrm{hi}$ & $23.05 \pm 0.2 \mathrm{chi}$ & $23.05 \pm 0.4 \mathrm{chi}$ & $66.41 \pm 0.3 \mathrm{~d}$ & Medium \\
\hline $\mathrm{V}$ & $4.81 \pm 0.1$ hij & $28.71 \pm 0.3 c$ & $28.71 \pm 0.1 \mathrm{c}$ & $56.87 \pm 0.5 \mathrm{~h}$ & Medium \\
\hline $\mathrm{W}$ & $3.97 \pm 0.0 \mathrm{jk}$ & $35.07 \pm 0.0 \mathrm{a}$ & $35.07 \pm 0.5 \mathrm{a}$ & $53.25 \pm 0.6 \mathrm{I}$ & Medium \\
\hline \multicolumn{6}{|c|}{ Santo Antônio do Leverger } \\
\hline $\mathrm{X}$ & $0.00 \pm 0.1 \mathrm{n}$ & $21.99 \pm 0.3 \mathrm{ij}$ & $21.99 \pm 0.6 \mathrm{ij}$ & $77.14 \pm 1.1 \mathrm{a}$ & Fije \\
\hline $\mathrm{Y}$ & $6.61 \pm 0.1 \mathrm{ef}$ & $23.29 \pm 0.0 \mathrm{gh}$ & $23.29 \pm 0.4 \mathrm{gh}$ & $64.43 \pm 0.5 \mathrm{e}$ & Medium \\
\hline \multicolumn{6}{|l|}{ Poconé } \\
\hline $\mathrm{Z}$ & $1.27 \pm 0.1 \mathrm{~m}$ & $22.11 \pm 0.1 \mathrm{hij}$ & $22.11 \pm 0.0 \mathrm{hij}$ & $71.28 \pm 01 \mathrm{c}$ & Medium \\
\hline
\end{tabular}

${ }^{\star}$ Means of three replicates. Different letters ij the same column ijdicate that the results differ statistically by Turkey’s test at $5 \%$ probability (p $<0.05$ ). 
of flour into the various classes, and samples were designated Out of Type when classification was impossible.

In the establishment of a standard to add value to artisanal cassava flour, the presence of samples labelled Out of Type is a serious problem, because it demonstrates undesirable variability in the product, which, although not uncommon, may hinder commercialization in the formal market. A certain variability should not be seen as a limitation to meet the consumer, because it is part of their identity and notoriety and a result of the regionalization of production processes. However if the criterion is consumer health, the limits established in the legislation cannot be relaxed. The aim of extension should be to support the producer in the need to maintain quality without compromising the artisanal character of his product.

When considering the Normative Instruction it was possible to establish the standard of the flour produced at the time of the study. Dry group flour with Medium granulation class comprised the majority of the samples followed by Dry group Coarse class flour for seven samples. It is interesting to consider that this distribution grouped as coarse flour two samples ( $\mathrm{J}$ and $\mathrm{K}$ ) of the three samples from the municipality of Jangada four of the six samples from Cuiabá (L, N, O, Q) and only one of the six samples from Acorizal. The remaining samples (R, S, U, V, W) were classified as Dry Class Medium flour.

The granulometry depends on the equipment used, particularly on the oven, since very high or low temperatures, higher or lower oven load and more or less intense pressing of the grated mass are responsible for the classes of flour (Brito et al., 2015) as they are cited in DRC No. 52 and by their standard (Brasil, 2011).

In the case of handmade flour, some variation of particle size is expected, and the large number of small groups that differ significantly (Table 2) confirms this expectation, but other characteristics are also present that reflect the personal processing choices by each manufacturer (Souza et al., 2008).

If hand made flours have variable granule sizes, then their labels should reflect those sizes, but this is not common. An example was reported by Álvares et al. (2013), where of 20 samples of artisanal flour sold in the Rio Branco market (Acre - Brazil), 18 labels were found in which the granulometry was incorrectly identified; therefore, almost all the samples had inadequate labels.

The yellow colour, in addition to the granulometry of the flour, is noted in the literature as one of the main factors that determine purchase, but colouring is more or less important in different regions of the country. In the Amazon region, cultivars with yellow pulp are valued, and the use of artificial colours is common even in very distant regions (Cereda \& Vilpoux, 2003). In contrast, the Centre-South region prefers flours with lighter colouring, such as Bijusadas (Brito et al., 2015).

In Figure 2, the colorimetry results for the 26 flour samples and their colour are grouped by Hunter Lab System. The area surrounded by a yellow line (Figure 2) shows the samples grouped by similar values of yellow colour $(+b)$, which was

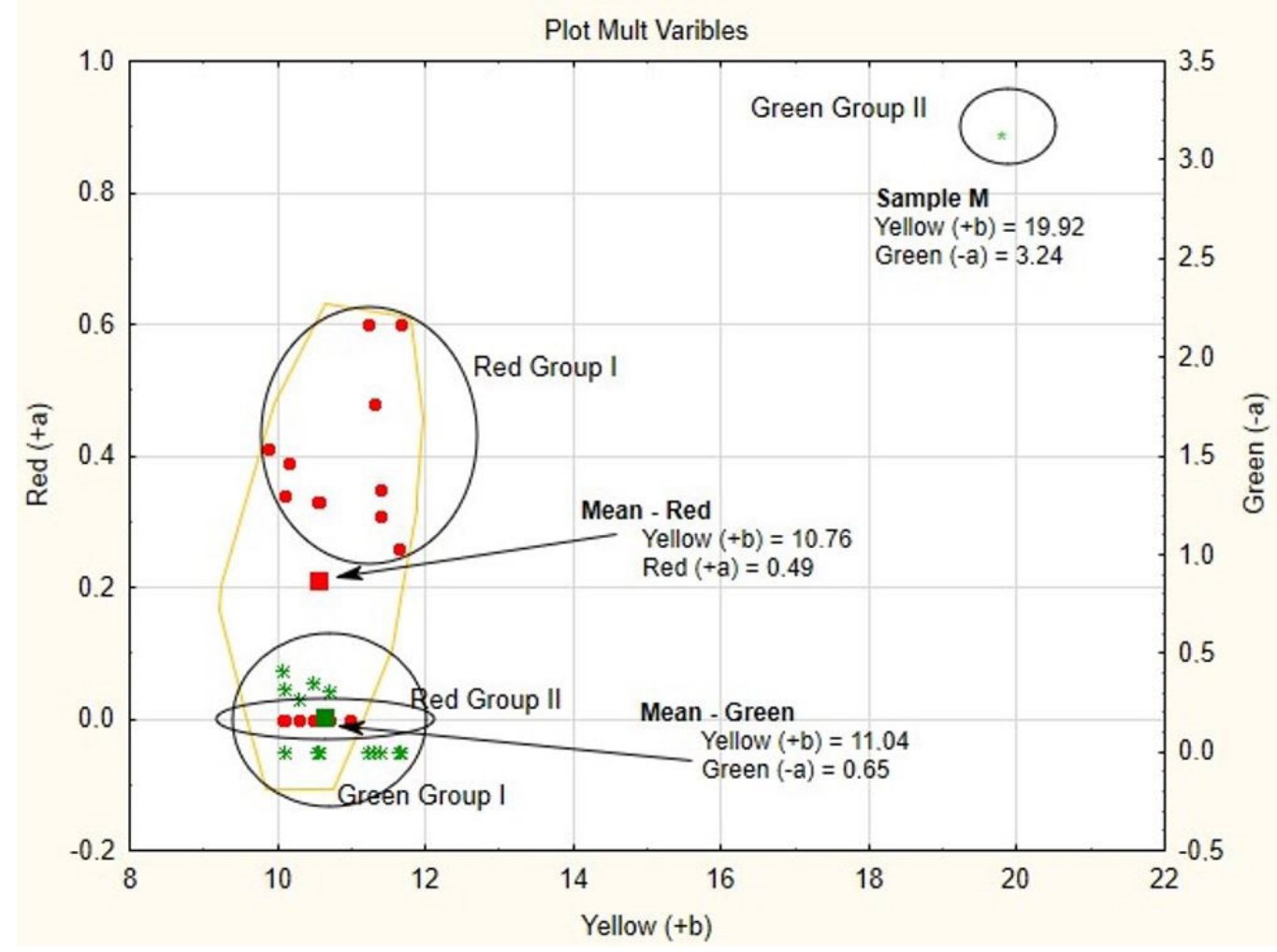

Figure 2. Multivariate plot of coloration according to the Hunter Lab System of cassava flours from Baixada Cuiabana (Mato Grosso, Brazil), sampled from June to August 2015. Municipalities: Rosário (A, B, C and D), Nossa Senhora do Livramento (E, F, G and H), Jangada (I, J and K), Cuiabá (L, M, N, O, P and Q), Acorizal (R, S, T, U, V and W), Santo Antônio do Leverger (X and Y), Poconé (Z). 
predominant in all flours, with values varying from 9.11 to 12.40 . Small variations can be observed between the red $(+a)$ and green (- a) tonalities, but the highlight of the coloration results was the outlier, sample M, with values of 3.24 for green (4.98 times higher than the mean) and 19.92 for yellow (1.82 times higher than the mean), indicating the presence of artificial colorants, which was confirmed in the laboratory and can be clearly observed in Figure 3.

The artificial yellow colorant tartrazine can be used in cassava flour without restriction. It was only possible to establish its presence without quantifying it. The addition of natural or artificial colorants to confer or reinforce the yellow colour in flours is not always necessary, since the root pulp may vary from orange to reddish in tone (Cereda \& Vilpoux, 2010), and this trait can be adjusted by changing the cultivation conditions. However, Freitas et al. (2011) reported that the yellow coloration of some flours marketed in the southwestern Amazon was a result of the addition of natural colorants such as turmeric (Curcuma longa L.) and annatto (Bixa orellana L.).

Classification into flour types, 1, 2, 3 and Out of Type, takes into account the contents of starch, fibre and ash. Humidity is the only one of the parameters related to maintaining food stability during storage. In the case of the flour samples analysed, all values were within the limits allowed by the legislation $(<13 \%)$.

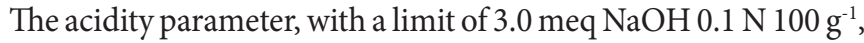
indicates possible fermentation or deterioration in the flour. However, even sample L, which presented the highest acidity

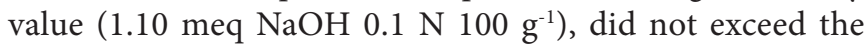
legislated limit.

The starch, fibre and ash contents of the flours are regulated by the legislation, and these presented significant variations (the maximum, average and minimum intervals.) that can be seen in the results presented in Table 3.
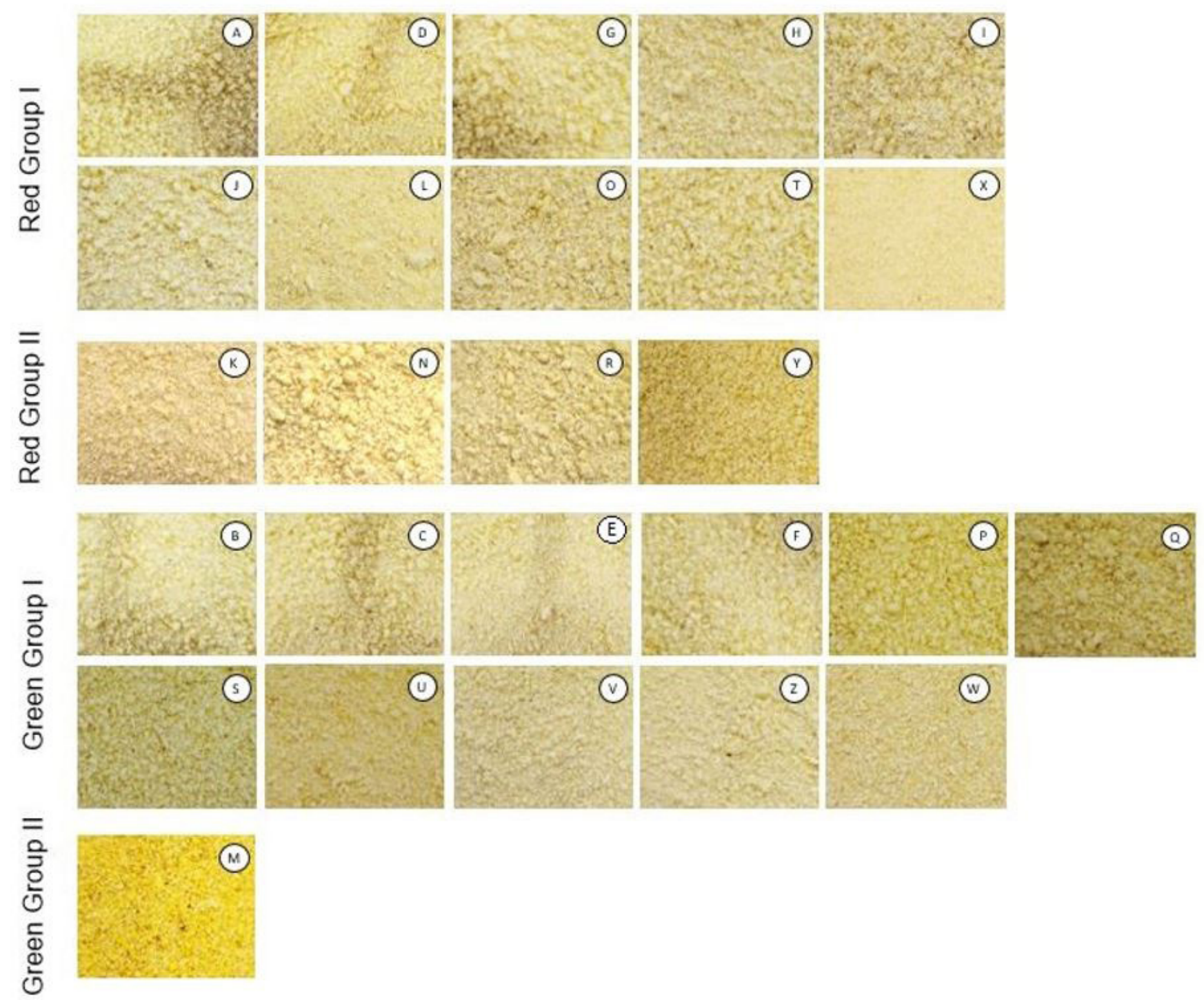

Figure 3. Characteristics of cassava flours from Baixada Cuiabana (Mato Grosso, Brazil), sampled from June to August 2015. Municipalities: Rosário (A, B, C and D), Nossa Senhora do Livramento (E, F, G and H), Jangada (I, J and K), Cuiabá (L, M, N, O, P and Q), Acorizal (R, S, T, U, V and W), Santo Antônio do Leverger (X and Y), Poconé (Z). 
According to flour standards, the Dry group is differentiated by granulometry (Fine, Medium or Coarse), and the starch content may vary in Type 1 (over $86.00 \%$ starch), Type 2 (82.00 to $86.00 \%$ ) or Type 3 ( 80.00 to $82.00 \%)$, but the ash and crude fibre contents should always be less than $1.4 \%$ and $2.3 \%$, respectively.

As can be observed in Table 2, the samples may be classified into 3 possible classes, with most samples having Medium granulation and only 7 having Coarse granulation (27\%). Only the $\mathrm{X}$ sample from Santo Antônio do Leverger was classified as

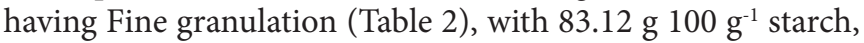

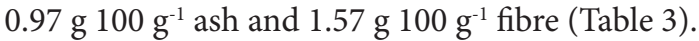

Among the 26 flour samples, only seven were classified into the granulometric class Coarse (Table 2), and in this case, the classification into types also accounted for the three components starch, ash and fibre. In Figure 4, the samples of the three types provided for in the legislation were grouped by component limits: higher than $86 \%$ for starch, less than $1.4 \%$ for ash and less than $2.3 \%$ for crude fibre.

Figure 4 emphasizes the variability found among the samples in relation to the limits of starch, ash and fibre marked on the lower, left and right axes, respectively. The continuous black lines surrounding the samples represent those that do not differ statistically within each type.

Type 1 samples included those collected in Acorizal (T) and Cuiabá (L), with limits higher than $86 \%$ of starch, ash less than $1.4 \%$ and crude fibre less than $2.3 \%$. Samples of Type 2 were most often collected in Cuiabá, where both samples had coarse granulometry (Q and N). Only sample V, collected in Acorizal, was classified as Type 3 .

Table 3. Acidity, Moisture, Ash, Starch, and Crude Fibre (Dry Basis) contents of 26 samples of cassava flours from Baixada Cuiabana (Mato Grosso, Brazil) sampled from June to August 2015.

\begin{tabular}{|c|c|c|c|c|}
\hline Analysis (Dry Basis) & Legislated Limit ${ }^{*}$ & Minimum & Median & Maximum \\
\hline Acidity (meq NaOH $100 \mathrm{~g}^{-1}$ ) & $\leq 3.00$ & 0.44 & $0.75 \pm 0.2$ & 1.10 \\
\hline Moisture (g $100 \mathrm{~g}^{-1}$ ) & $\leq 13.00$ & 6.07 & $8.25 \pm 1.4$ & 11.62 \\
\hline $\operatorname{Ash}\left(g_{\left.100 g^{-1}\right)}\right.$ & $\leq 1.40$ & 0.87 & $1.33 \pm 0.28$ & 2.07 \\
\hline Starch $\left(\mathrm{g} 100 \mathrm{~g}^{-1}\right)$ & $* *$ & 70.56 & $82.76 \pm 5.1$ & 92.18 \\
\hline Crude Fibre (g $\left.100 \mathrm{~g}^{-1}\right)$ & $\leq 2.30$ & 1.04 & $2.46 \pm 0.8$ & 4.12 \\
\hline
\end{tabular}

${ }^{*}$ Normative Instruction 52 (2011). ${ }^{*}$ Type $1, \geq 86 \%$; Type 2, $\geq 82 \%$ and $\leq 86 \%$; Type $3, \geq 80 \%$ and $\leq 82 \%$.

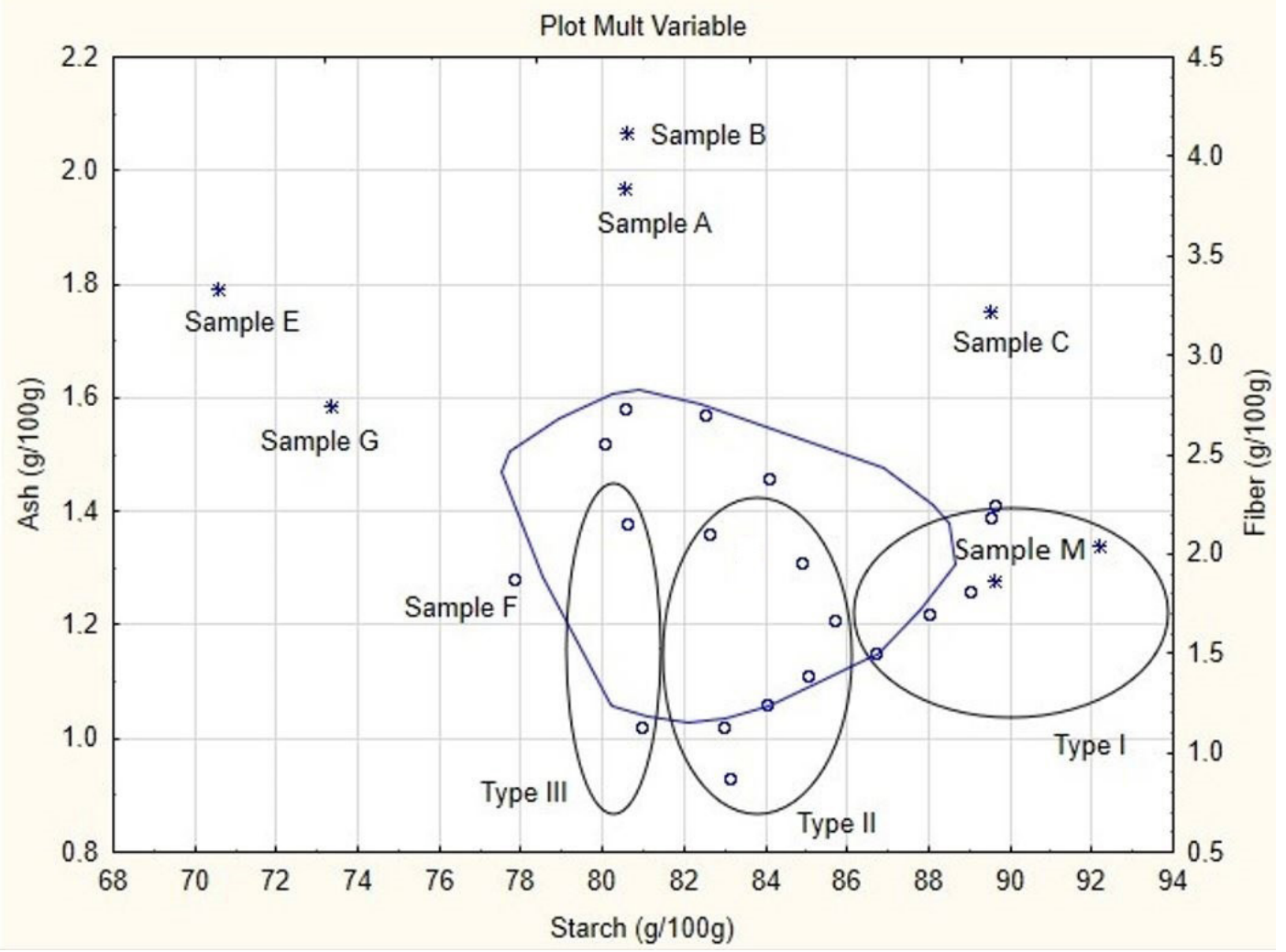

Figure 4. Multivariate plot of Starch, Ash and Fibre and Type classifications for Brazilian cassava flour from Baixada Cuiabana (Mato Grosso, Brazil), sampled from June to August 2015. The samples with an asterisk $\left(^{*}\right)$ are those that differed greatly from the clusters, the samples with an $\left(^{\circ}\right)$ are all in the main cluster. Full lines surround samples that did not differ for each type. The blue line surrounds most samples framed as Out of Type. 
Finally, two samples from the Jangada municipality (J and K) and one $(\mathrm{O})$ from Cuiaba did not meet the type requirements, and the class would have to be printed on these packages with the words Out of Type.

Generally, Type 1 flours were more frequently produced in Acorizal, with three samples (S, T and V), followed by one from Cuiabá (L) and one from Santo Antônio do Leverger (Y). One sample of Type 2 cassava flour was collected in each of Rosário Oeste (D), Jangada (I), Cuiabá (P), Santo Antônio do Leverger $(\mathrm{X})$, and Poconé $(\mathrm{V})$, and two Type 2 samples (R and $\mathrm{W}$ ) were collected from Acorizal. Finally, 7 samples did not fit into any of the classifications for type, denoting problems with the limits established by the legislation. The most serious situation was for samples E, F and G, collected in Nossa Senhora do Livramento, which would receive the denomination Out of Type. The same problem was found for three samples from Rosario Oeste (A, B and C) and one from Cuiabá (M). This last is the same sample that stood out for presenting artificial colorant. Flours outside the Type may be marketed as Out of Type, complying with requirements related to marking or labelling.

The establishment of a minimum starch content is particularly important in order to avoid cheating by mixing the flour with the residue from the extraction of cassava starch (bran), which is often sold as flour. Low starch content also occurs when the grated mass has been previously washed to extract part of the starch, as is common in regional processes. This removed starch is marketed as sweet or sour starch (Leonel \& Cereda, 2002). High fibre and ash content may also indicate fraud, but may instead reveal problems in processing if the flour contains impurities such as pieces of branches, wood or soil or sand from the cassava roots.

Generally, the results indicated that all samples could be classified as yellow flour of the Dry group with low acidity, with mainly Medium granulation. Of 26 total samples, approximately $60 \%$ of the flours could be marketed with this standard, because they were within the standards. However, some municipalities differed and should receive focused attention by the Government to promote valorisation and uniformity.

Although they presented greater uniformity in granulometry, the municipalities of Rosário Oeste and Nossa Senhora do Livramento were the ones that presented the highest number of flour samples that would receive Out of Type labels, because they did not meet the criteria for approved types. This lack of classification was due to ash and fibre contents above or starch contents below the established limits. Although the parameters of the Brazilian legislation facilitate the identification of fraud, on the other hand it may be very restrictive for artisanal cassava flour, where these parameters vary greatly depending on different cultural processes that provide the identity and notoriety of the product.

The samples from Cuiabá showed the most varied identity, with different classes and types in the 6 samples collected, showing little care in processing. The municipality of Acorizal also stands out because it better represents the identity of the Baixada Cuiabana flour, with 6 samples with the characteristics of Medium granulation across the three types, 1, 2 and 3.
Type 2 was the most frequent for all samples, regardless of Fine, Medium or Coarse granulometry. Type 2 samples were found in the municipalities of Rosário Oeste, Jangada, Cuiabá, Acorizal, Santo Antônio do Leverger and Poconé. Type 1 flour was represented by three samples from Acorizal and one from Santo Antônio do Leverger. Finally, Type 3 flour was only identified in a sample collected in Acorizal.

The municipality of Cuiabá, as well as Acorizal, was where a greater number of flour samples were collected, six in each, allowing a greater variability of classes and types. Cuiabá, because it is the capital of the state, is closer to consumers and distributors, and probably because of this, its producers are concerned with flour with a greater range of characteristics. Cuiabá was the municipality where the only flour sample containing artificial yellow colorant was found. At Acorizal, no Out of Type samples were identified, which indicates that this region was the closest to manufacturing products suitable for the market.

Although some municipalities presented more uniform flours in regard to granulometry and colour, most municipalities were characterized by high variability, as expected and reported for artisanal processes. The fact that approximately $60 \%$ of the cassava flour samples collected in the municipalities that represent Baixada Cuiabana do not comply with the specific legislation that defines the conditions of commercialization represents a risk to the continuation of cassava processing in this area. Because of the importance of this industry in maintaining an active bank of ethno-varieties of cassava plants, it would be advisable to organize and train the producers to better control the flour production process as a means of preserving their standard.

\section{Conclusions}

These results allow us to establish a standard pattern for the flours produced and commercialized in Baixada Cuiabana (Mato Grosso, Brazil), which are characterized by dryness and yellow colour. Most samples can be classified as Medium class, followed by a small number of Coarse class. Type 2 predominated in the majority of the samples, but a significant number would receive the classification Out of Type.

Taking into account the requirements established by RDC No. 52 , it can be stated that approximately $60 \%$ of the samples would be difficult to commercialize because they present higher ash and crude fibre contents and because they have starch contents lower than the allowed limits. These results show that flour sales are at risk in the establishments visited.

\section{Acknowledgements}

The authors are grateful to Dra. Dolorice Moreti of the Empresa Mato-grossense de Pesquisa, Assistência e Extensão Rural-EMPAER and Dra. Eulália Soler Sobreira Hoogerheide of Embrapa Agrossilvipastoril for their collaboration in this study.

\section{References}

Álvares, V. S., Costa, D. A., Felisberto, F. A., Silva, S. F., \& Madruga, A. L. S. (2013). Atributos físicos e físico-químicos da farinha de mandioca artesanal em Rio Branco, Acre. Revista Caatinga, 26(2), 50-58. 
Association of Official Analytical Chemists - AOAC. (2000). Official methods of analysis of of the Association of Official Analytical Chemists (14th ed.). Arlington: AOAC.

Brasil, Ministério da Agricultura Pecuária e Abastecimento. (2005, Setembro 08). Instrução Normativa $\mathrm{n}^{\circ} 24$, de 08 de setembro de 2005. Manual operacional de bebidas e vinagres e anexos. Diário Oficial [da] República Federativa do Brasil.

Brasil, Ministério da Agricultura, Pecuária e Abastecimento. (2011, Fevereiro 18). Estabelecer o regulamento técnico da farinha de mandioca na forma da presente instrução normativa e dos seus anexos I, II e III. Resolução Nº 7, de 18 de fevereiro de 2011. Diário Oficial [da] República Federativa do Brasil.

Brito, V. H. S., Silva, E. C., \& Cereda, M. P. (2015). Digestibilidade do amido in vitro e valor calórico dos grupos de farinhas de mandioca brasileiras. Brazilian Journal of Food Technology, 18(3), 185-191. http://dx.doi.org/10.1590/1981-6723.2714.

Cereda, M. P., \& Vilpoux, O. F. (2003). Farinhas e derivados. In M. P. Cereda, \& O. F. Vilpoux (Eds.), Tecnologia, usos e potencialidades de tuberosas amiláceas Latino Americanas (cap. 21, pp. 621-642). São Paulo: Fundação Cargil.

Cereda, M. P., \& Vilpoux, O. (2010). Metodologia para divulgação de tecnologia para agroindústrias rurais: exemplo do processamento de farinha de mandioca no Maranhão. Revista Brasileira de Gestão e Desenvolvimento Regional, 6(2), 219-250.

Chisté, R. C., Cohen, K. O., Mathias, E. A., \& Ramoa, A. G. A. Jr. (2007). Estudo das propriedades físico-químicas e microbiológicas no processamento da farinha de mandioca do grupo d'água. Food Science and Technology, 27(2), 265-269. http://dx.doi.org/10.1590/ S0101-20612007000200009.

Demiate, I. M., Konkel, F. E., \& Pedroso, R. A. (2001). Avaliação da qualidade de amostras comerciais de doce de leite pastoso: composição química. Ciência e Tecnologia de Alimentos, 21(1), 108-114. http:// dx.doi.org/10.1590/S0101-20612001000100023.

Dias, L. T., \& Leonel, M. B. (2006). Caracterização físico-química de farinhas de mandioca de diferentes localidades do Brasil. Ciência e Agrotecnologia, 30(4), 692-700. http://dx.doi.org/10.1590/S141370542006000400015 .

Freitas, C. G., Farias, C. S., \& Vilpoux, O. F. (2011). A produção camponesa de farinha de mandioca na Amazônia Sul Ocidental. Boletim Goiano de Geografia, 31(2), 29-42.

Instituto Brasileiro de Geografia e Estatística - IBGE. (2016). Levantamento sistemático da produção agrícola. Retrieved from http://www.ibge.gov.br/home/estatistica/indicadores/agropecuaria/ lspa/default_publ_completa.shtm

Instituto Adolfo Lutz - IAL. (1985). Normas analíticas do Instituto Adolfo Lutz: métodos químicos e físicos para análise de alimentos. 3. ed. São Paulo: IAL.

International Organization of Vine and Wine - OIV. (2012). Compendium of international methods of wine and must analysis (OIV - 18, MAE-AS315-08-COLSYN). Paris: OIA.

Leonel, M., \& Cereda, M. P. (2002). Caracterização físico-química de algumas tuberosas amiláceas. Food Science and Technology, 22(1), 65-69. http://dx.doi.org/10.1590/S0101-20612002000100012.

Mundin, S. M., Kluczkovski, A. M., Rodrigues, J. C., Brito, V. H., \& Fernandes, O. C. (2015). Cyanide influence on the growth of mycotoxigenic fungi from cassava flour in vitro. African Journal of Microbiological Research, 9(17), 1184-1188. http://dx.doi.org/10.5897/ AJMR2015.7433.

Oliveira, V. A., Oliveira, T. W. N., Alencar, M. V. O. B., Peron, A., \& Sousa, J. M. C. (2014). Relação entre consumo alimentar da população nordestina e o alto índice de câncer gástrico nesta região. Revista Intertox de Toxicologia, Risco Ambiental e Sociedade, 7(3), 06-24.

Prado, M. A., \& Godoy, H. T. (2003). Corantes artificiais em alimentos. Alimentos e Nutrição, 14(2), 237-250.

Nelson, N. A. (1944). Pthotometric adaptation of the Somogyi method for the determination of glucose. The Journal of Biological Chemistry, (153), 375-380.

Silva, I. R., Cardoso, R. C. V., Goes, J. A. W., Druzian, J. I., Vidal, P. O. Jr., \& Andrade, A. C. B. (2016). Food safety in cassava "flour houses" of Copioba Valley, Bahia, Brazil: Diagnosis and contribution to geographic al indication. Food Control, 72(1), 1-8. https://doi. org/10.1016/j.foodcont.2016.07.034.

Somogyi, M. (1945). Determination of blood sugar. The Journal of Biological Chemistry, (160), 69-73.

Souza, G. C., \& Amaral, C. N. (2015). Política territorial e os agricultores tradicionais do território da baixada cuiabana, Mato Grosso. Guaju. Matinhos, 1(1), 64-89.

Souza, J. M. L., Alvares, V. S., Leite, F. M. N., Reis, F. S., \& Felisberto, F. A. V. (2008). Caracterização físico-química de farinhas de mandioca oriundas do município de Cruzeiro do Sul - Acre, Ciências Exatas e da Terra. Ciências Agrárias e Engenharias, 14(1), 43-49. http:// dx.doi.org/10.5212/Publ.Exatas.v.14i1.043049.

Statsoft. (2016). Statistica data analysis software system. Version 13.1. Tulsa: Statsoft Inc. 